\title{
Modos ficcionais e historicidade: Charles Dickens, Franz Kafka, Raymond Carver
}

\author{
Fictional Modes and Historicity: Charles Dickens, Franz Kafka, \\ Raymond Carver
}

\author{
Gustavo Naves Franco \\ gnavesfranco@gmail.com \\ Professor Adjunto \\ Universidade Federal do Estado do Rio de Janeiro \\ Rua Assunção, 450/319 \\ 22251-030 - Rio de Janeiro - RJ \\ Brasil
}

\begin{abstract}
Resumo
O artigo propõe uma leitura comparativa das obras de Charles Dickens (1812-1870), Franz Kafka (1883-1924) e Raymond Carver (1938-1988), com base na "Teoria dos Modos" de Northrop Frye. Neste percurso, os diferentes usos do modo cômico e do modo trágico são analisados como signos de historicidade que acompanham transformações culturais verificadas entre os séculos XIX e XX no ocidente. Observa-se, então, que os contrapontos modais recorrentes em cada autor criam uma dinâmica de identidades e diferenças entre suas narrativas, bem como entre os textos e as circunstâncias contextuais em que emergem. E, por fim, é indicada uma possibilidade de mobilização desses recursos analíticos para o entendimento de aspectos da relação entre literatura e sociedade no período pós-1945, quando a proeminência do modo trágico confere relevância distintiva às manifestações pontuais do cômico na ficção.
\end{abstract}

\section{Palavras-chave}

Ficção; Historicidade; Narrativas.

\begin{abstract}
This article proposes a comparative reading of the works by Charles Dickens (1812-1870), Franz Kafka (1883-1924) and Raymond Carver (1938-1988), based on Northrop Frye's "Theory of Modes". The different usages of the tragic mode and the comic mode are analyzed as signs of historicity that follow cultural transformations observed between the $19^{\text {th }}$ and the $20^{\text {th }}$ centuries in the Western world. The recurrent modal counterpoints of each writer are seen to create a dynamic of identities and differences in the relation between their narratives, and in the relations among the texts and their contextual circumstances. And, finally, the article indicates a possibility of using these analytical resources in order to understand the dialogue between literature and society in the post-1945 period, when the prevalence of the tragic mode confers a distinctive relevance to the more punctual manifestations of the comic mode.
\end{abstract}

\section{Keywords}

Fiction; Historicity; Narratives. 
Embora com frequência tenham sido consideradas abordagens excludentes dos fenômenos da escrita, a Teoria Literária e a História Literária podem hoje ser articuladas em um movimento complementar para a compreensão de seus objetos, tendo sempre como horizonte o enriquecimento das experiências de leitura e das dinâmicas culturais em que elas se inserem. Assim, mobilizando também os recursos da Literatura Comparada, este artigo propõe um caminho para a análise de alguns desdobramentos da narrativa nos séculos XIX e XX, concentrando-se na evolução de estilos e formas literárias e, ao mesmo tempo, examinando sua inserção nos ambientes históricos em que se operam estas mudanças. Trata-se, portanto, de investigar as variações internas do texto como indícios de uma historicidade que se revela nas modulações da linguagem, dos ritmos e dos enredos, percebidos como veículos privilegiados para a exposição de transformações substanciais da experiência humana.

Mais especificamente, o enfoque do artigo será conferido às variações, conexões e contrapontos de dois "modos" ficcionais - o modo cômico e o modo trágico - nos autores selecionados para a análise. Para isso serão recuperadas algumas premissas básicas da "Teoria dos Modos" proposta por Northrop Frye em seu Anatomy of Criticism (1957), de maneira a aproveitá-la tanto para a elucidação de certos procedimentos literários quanto para o entendimento das sociedades em que estes emergem. A primeira justificativa para uma abordagem deste tipo está no fato de que a opção pelo trágico ou pelo cômico como tom narrativo tem sempre muito a dizer sobre as circunstâncias culturais da produção de um texto e a maneira como ele reage criativamente a seu tempo. Além disso, as nuances e possibilidades da dinâmica do cômico e do trágico requerem sempre uma renovação dos esforços voltados a interpretá-las. Mas cabe notar, desde logo, que a Teoria dos Modos não se confunde com a Teoria dos Gêneros Literários, uma vez que diz respeito a aspectos mais sutis e oscilantes do estilo narrativo do que à circunscrição dos textos a uma categoria formal definida.

Por outro lado, a exposição do argumento exigirá a delimitação de alguns recortes, e dois subgrupos precisarão ainda ser isolados na proposta: a literatura inglesa de meados do século XIX e a literatura estadunidense da segunda metade do século XX. Fica então a ressalva de que, em uma perspectiva comparativa, este processo de subdivisão poderia continuar indefinidamente, de tal modo que a própria presunção da existência de uma "literatura inglesa" ou de uma "literatura estadunidense" ficaria comprometida pelas muitas variações internas de cada unidade de análise. Essas unidades, portanto, devem ser construídas com algum grau de coerência interna durante a exposição do argumento, de acordo com a questão mobilizada para a leitura dos textos. Ou seja, sua pertinência está condicionada à evidenciação de recorrências específicas nesta elaboração comparativa. O mesmo vale para as unidades temporais: as referências ao "século XIX" e ao "século XX" não pretendem de maneira alguma reduzir experiências históricas tão vastas ao que será exposto aqui em termos de variação de modos ficcionais, ainda mais levando em conta os recortes linguísticos e culturais já mencionados. Espera-se que a evolução do argumento confira vida própria para o uso dessa periodização, a princípio tão arbitrária. 
Um último pressuposto teórico-metodológico precisa ser mencionado. Partiremos de uma compreensão do fenômeno literário como lugar de exposição e inovação de dinâmicas relacionais que não é determinado por quaisquer instâncias externas a ele, mas surge do mesmo campo de possibilidades que gera outros produtos da experiência humana, como os modos de organização da vida social e os sistemas econômicos. Em todos os casos, verifica-se um processo de criação ao mesmo tempo autônomo e interdependente, com a expressão de aspectos culturais cuja síntese nunca pode ser identificada em um único veículo de sua expressão, mas apenas investigada em suas variadas dimensões concretas. Todas essas dimensões oferecem seus indícios para a investigação do ambiente histórico de um lugar e de uma época, e nenhuma delas é capaz de esgotar sozinha esta investigação. Portanto, em cada fenômeno podem ser observadas especificidades, variações e alternativas que conferem novas perspectivas à compreensão do todo intangível e nunca plenamente determinável.

É particularmente importante considerar essa ambivalência da identificação e da diferença na análise da produção literária dos últimos dois séculos na Inglaterra e nos Estados Unidos. Em primeiro lugar, porque será o caso de buscar um maior entendimento, desta vez através do recurso a texto de ficção, dos mecanismos relacionais que também estiveram presentes em desdobramentos de sistemas econômicos e políticos de grande impacto no cenário global da modernidade. Em segundo lugar, porque a arte da ficção jamais se restringe a por em operação tais mecanismos, uma vez que requer o contraste e 0 estranhamento para adquirir envergadura dramática. Nesta perspectiva, qualquer referência a um "autor inglês" ou à "literatura inglesa", por exemplo, de maneira alguma diz respeito aqui a uma plena identificação com o espectro indefinido de vetores culturais da construção histórica que convencionalmente chamamos de "Inglaterra". Tampouco se trata de mera oposição, naturalmente, mas de agentes e fenômenos que dialogam com esse contexto em movimentos complexos de aproximação e afastamento, imprescindíveis à dimensão criativa do ofício literário.

Feitas essas observações, uma indicação mais sintética das conclusões deste estudo pode ser já formulada. No percurso, seguindo a linha de análise escolhida, veremos como, entre os autores ingleses da primeira metade do século XIX, a proeminência das modulações da comédia, encontrada também em processos de sociabilidade e ritmos econômicos da época, teve como relevante contraponto, particularmente na obra de Charles Dickens, a percepção do trágico como um fenômeno individual, social e histórico que nunca deveria ser negligenciado, sob o risco de perda de contato entre a literatura e a experiência. Inversamente, no universo cultural comparativamente mais fragmentado, violento e apocalíptico da experiência estadunidense (e do século XX de modo geral), alguns aspectos do cômico reaparecem com notável singularidade e ineditismo, sem prejuízo do critério de verossimilhança e da articulação entre ritmos ficcionais e regimes de historicidade, como será assinalado na obra de Raymond Carver.

Para que a discussão ganhe consistência, será útil incorrer em uma digressão intermediária sobre a obra de Franz Kafka, a princípio alheia ao recorte 
da pesquisa, mas que deve ter sua menção justificada por conexões diretas e indiretas com os autores discutidos. Questões relativas ao mercado literário da virada do século XIX para o XX também devem ser brevemente consideradas. Enfim, uma vez completada esta trajetória, será possível abrir uma discussão sobre algumas implicações desta retomada da teoria dos modos ficcionais para a análise da arte, da sociedade e do sentimento histórico contemporâneo.

\section{Charles Dickens: o demônio está nos detalhes}

No breve ensaio intitulado Ideia de uma história universal de um ponto de vista cosmopolita, de 1784, Immanuel Kant propôs a "insociável sociabilidade" do homem como princípio definidor das disposições naturais em jogo no movimento histórico. Sucintamente, o filósofo circunscrevia no conceito a dupla tendência dos indivíduos à associação e ao isolamento, à identidade e à diferença, à concórdia e ao desacordo, sendo a alternância e o contraponto entre elas responsável pelas diferentes formas e resultados do relacionamento humano. Desconsiderando por hora as implicações dessa percepção para a Teoria da História de Kant, podemos encontrar aí um ponto de partida para a delimitação do modo cômico e do modo trágico como fundamentos das relações internas entre os signos do artefato literário, e segundo sua mobilização para este estudo. De um lado, estão as forças centrípetas de coesão, negociação e harmonia que predominam nos desdobramentos da comédia; do outro, os vetores de fragmentação e desentendimento, de dispersão e de choque, que

124 determinam a ação trágica.

Northrop Frye qualificou essa distinção utilizando como referência a obra de William Shakespeare, onde os modos ficcionais são mais claramente verificados isoladamente, nos movimentos de suas tragédias e comédias. Assim, de um lado, estão as ficções em que o herói é isolado de sua sociedade, e, de outro, as ficções onde ele é incorporado a ela. Ou seja: nas tragédias, a vontade, as paixões e os valores individuais entram em choque irreconciliável entre si e com as estruturas sociais vigentes, enquanto as comédias se caracterizam pela demarcação de um território comum para o acordo, representado por desfechos alegres e otimistas. Em oposição à catástrofe trágica, temos então a anástrofe cômica: o instante de reconciliação entre os membros de uma sociedade ameaçada, que no percurso da comédia se reconfigura em uma metamorfose renovadora, contando para isso com a boa-vontade, o espírito de compromisso, o bom senso e certa habilidade pragmática da parte de seus componentes.

Estão aí listados alguns dos atributos da "sinceridade", no sentido em que Lionel Trilling, em seu Sincerity and Authenticity (1972), associou-os à arte e à sociedade da Inglaterra do século XIX, e mais especificamente à obra de Jane Austen, onde repercute o universo das comédias de Shakespeare. E vale observar que as modulações das trajetórias das heroínas de Austen nem de longe representam movimentos de uma crescente conformidade às convenções, e sim a busca de uma adequação do espírito à forma de um destino a ser desvendado, cuja revelação determina a forma de cada romance em particular, mas nunca do "romance" austeniano de maneira geral. A própria noção de common sense, 
portanto, prescinde de uma lei rígida e invariável, estando sempre relacionada a situações singulares, nas quais experiência e boa vontade devem orientar a ação dos personagens centrais.

Em consonância com esses desdobramentos da narrativa, mas exibindo alguns outros traços importantes, está a obra de Charles Dickens. Neste caso, embora a análise revele tramas mais padronizadas e até previsíveis em suas linhas gerais, a riqueza de detalhes na dinâmica discursiva e nas flutuações do estilo confere grande relevo aos contrapontos modais presentes na narrativa, pondo inclusive em maior risco a unidade conciliatória a ser consagrada nos desfechos. Isto se dá particularmente no ciclo de romances que começa com The Old Curiosity Shop (1840-1841) e vai até Great Expectations (1860-1861). Neles, a galeria folhetinesca de personagens idiossincráticos, apatetados ou monomaníacos de cada texto serve tanto ao prazer da leitura quanto à contraposição de suas peculiaridades ao bom e sólido common sense que deve prevalecer no final. Mas, com frequência no decurso dos relatos, o mundo parece de tal maneira fora dos eixos que este final só pode mesmo ser encarado como uma convenção artificiosa.

Sem dúvida, e apesar das aparências, em Dickens as coisas sempre têm conserto. Mesmo aquilo que parece totalmente sem sentido acaba ganhando um significado à luz da providência que termina por dar forma ao enredo, e o nonsense que se insinua em algumas passagens é de certa maneira anulado pela última palavra da narrativa. Porém, e este é o ponto a ser ressaltado com maior atenção, há na orfandade dos personagens de Dickens um desvio radical em relação à normalidade da vida que ainda reverbera nos desfechos, uma vez que é ele que instaura o próprio movimento de cada romance. $\mathrm{E}$ este é um problema diante do qual mesmo as mais completas teodiceias cristãs têm dificuldade em prosseguir, ao buscar explicações para a existência do mal no mundo. Pois englobar o sofrimento de uma criança em qualquer sistema de compensações, ou buscar anulá-lo da perspectiva de reviravoltas providenciais, vai sempre além do que mesmo nossa boa vontade está disposta a tolerar. Ou seja: por mais que uma sensação de confiança seja sempre preservada nos romances de Dickens, em algumas dessas passagens a voz de seu narrador, diante do absurdo do sofrimento a que seus protagonistas são submetidos, estabelece um contraponto modal de grande peso, entre outros fatores pelo contraste que estabelece com o todo da narrativa. No conjunto, portanto, Dickens nunca deixa de ser um comediógrafo. Mas o demônio está nos detalhes, e os detalhes fazem toda diferença.

Este é um ponto crucial para o desenvolvimento do presente estudo. Em $A$ Natural Perspective: the Development of Shakespearean Comedy and Romance (1965), Northrop Frye tratou de um fenômeno análogo ao discutir a ambivalência e o desconforto que está presente mesmo em algumas das tramas mais alegres de Shakespeare, e a parcela de violência, dor e sofrimento que as impede de se tornar plenamente bem resolvidas em suas promessas de felicidade e esperança. No decurso dos textos, há sempre um lamento trágico de um Parolles ou de um Shylock que denuncia algo incompatível com esses desfechos, e cuja lembrança 
permanece para espectadores mais atentos, mesmo em meio às festividades idílicas do final. Do mesmo modo, no interior dos enormes romances de Dickens, podem ser encontradas passagens que contradizem radicalmente 0 espírito otimista do conjunto. Portanto, se hoje sabemos que a aparentemente cômoda e afortunada sociedade burguesa do século XIX possuía um fundo de brutalidade e exclusão que remonta às relações entre Próspero e Calibã, pode- se dizer que, em uma visão de conjunto, a cultura britânica oitocentista foi uma cultura da comédia romântica, da conciliação reformista e de habilidosos arranjos retificadores do mundo - porém no detalhe, em instantes pontuais, dava-se uma suspensão dessa segurança, imiscuindo-se nela uma angústia irremediável e fundamental.

Voltando a Kant e à sua Ideia de uma história universal de um ponto de vista cosmopolita, também em um registro relativamente otimista, temos a perspectiva de que a disposição natural da sociabilidade acabaria por assumir certa proeminência sobre as tendências ao isolamento e à dissenção na história humana. Mas isso só se tornaria evidente, segundo o filósofo, em um muito longo e muito tortuoso processo, feito de idas e vindas, avanços e retrocessos, ações e reações, em que os conflitos e as guerras obrigariam a espécie a encontrar "uma lei de equilíbrio para uma oposição em si mesmo saudável", contando para isso com "conceitos", "experiência" e "boa vontade", em múltiplas negociações e arranjos pragmáticos pontuais (cf. KANT 2003). Ainda assim, jamais uma solução completa e estável seria alcançada, e apenas 126 uma aproximação a ela seria viável ("de uma madeira tão retorcida, da qual o homem é feito, não se pode fazer nada de reto"). Deste modo, se o panorama geral da visão kantiana da história traz analogias com a forma da comédia, ele preserva uma irresolução trágica de fundo, impedindo que uma compreensão irrealista do todo histórico e social se sobreponha à realidade ambivalente das disposições humanas.

No momento em que escrevia, porém, Kant observava igualmente que a sociedade de seu tempo padecia "do pior dos males, sob a aparência enganosa do bem-estar exterior" (KANT 2003, p. 16). O excesso de otimismo, de confiança no futuro, e a crença determinista em um suposto processo civilizatório (favorecidos pelo desenvolvimento da técnica, por avanços científicos, e pela crescente legislação da conduta) j já eram então fenômenos perceptíveis. "Mediante a arte e a ciência, somos cultivados em alto grau. Somos civilizados até a saturação por toda espécie de boas maneiras e decoro sociais", ele acrescentava, antecipando o diagnóstico de um problema que se tornaria ainda mais evidente a partir da segunda metade do século XIX, em todo o contexto europeu. No que se refere ao tópico deste estudo, pode-se dizer que, assim como assuntos desagradáveis passavam a ser cada vez mais proscritos das conversas na sala de jantar, o modo trágico seria também efetivamente anulado no âmbito da narrativa. E, com isso, as formas literárias em que predominava o cômico teriam desdobramentos que ainda hoje repercutem na avaliação de todo o conjunto de suas manifestações. 


\section{Franz Kafka: ligeiras e diversas demoras}

A comédia romântica nunca foi objeto de grande estima para a crítica literária ou para a filosofia acadêmica. Isso se deve, em parte, a aspectos constitutivos do gênero, como o apelo ao senso comum, certa simplicidade discursiva e temática, e o alegre otimismo (intelectualmente pouco sofisticado) de seus desfechos. No geral, tais características estão presentes nas comédias de Shakespeare, onde a mesma carência de sofisticação não deixa de operar com uma série de sutilezas próprias, e são recorrentes em Jane Austen e Charles Dickens, também aqui com apurados movimentos em torno de um incerto eixo de equilíbrio. No entanto, durante o século $X X$, a comédia romântica passou a ser vista também como uma forma artística enrijecida por convenções vazias, associada à indústria de entretenimento de massas. E esses fatores, mais diretamente ligados a fenômenos do final do século XIX, foram, justificadamente, os maiores responsáveis pelo declinante prestígio do gênero junto à crítica.

O processo se deu na sociedade e na arte europeias em consonância com os temores registrados por Kant: ao acúmulo de regras de conduta e de convenções sociais cuja razão de ser se tornava cada vez menos identificável, correspondeu a demarcação das convenções formais e procedimentos pré-definidos na composição literária, dando o caráter de absoluta determinação ao que antes precisava ser construído e negociado no texto e na leitura. 0 common sense se converteu no "lugar-comum", e as questões éticas foram substituídas por problemas de etiqueta, tornando monótono o que antes apresentara importantes variações tonais. Assim, o modo trágico ficava definitivamente proscrito da comédia romântica, que perdia também em graça, desenvoltura e humor o que ganhava em segurança, previsibilidade e normatização técnica. A trajetória da composição de viés cômico deixava de ser a da reintegração de uma ordem comunitária através do improviso, porque passava a lidar com enredos e universos que jamais encaravam uma verdadeira ameaça à própria integridade.

Como observou Siegfried Kracauer, no ensaio "Sobre livros de sucesso e seu público", de 1933, depois reunido em O ornamento da massa, a crescente percepção do esvaziamento da experiência burguesa favorecia um engessamento ainda maior de convenções e protocolos. Para uma classe que confrontava a perda de sua identidade diante das multidões urbanas, tratava-se de encontrar mecanismos de preservação e controle de seus hábitos e limites, ainda que através de reiterações automáticas e destituídas de qualquer contato real com o mundo informe das metrópoles. Ao mesmo tempo, esse mundo se mostrou um mercado consumidor ávido e compulsivo de enredos românticos forjados na linha de produção literária, em uma dinâmica que depois se transferiu para o cinema e envolveu outras estruturas narrativas congêneres, sobretudo o relato policial. A avidez do consumo se explica, em parte, porque a própria incerteza da vida urbana favorecia a busca por artefatos formais que oferecessem o exato inverso dessa experiência, através de uma clara demarcação de identidades e da certeza de um final feliz. Já a compulsão é decorrente da total insuficiência desses mesmos artefatos para aplacar a necessidade de segurança. 
Do ponto de vista das relações entre literatura e sociedade, ou entre gêneros literários e público leitor, este não deixa de ser um tópico de grande interesse. Mas há outra sequência de transformações, relacionadas aos assuntos tratados até aqui, que pode nos encaminhar novamente para a análise de obras de maior complexidade estética. Será então o caso de observar como, a princípio em uma pontual operação de estranhamento em relação a hábitos recebidos da tradição oitocentista, a comédia passou a ter sua forma implodida internamente no romance, com uma inserção mais definitiva do modo trágico em seu desfecho. Isso foi o que se passou, particularmente - porém com grande repercussão para os ulteriores desdobramentos na literatura do século $X X-$, no primeiro romance de Franz Kafka.

Recordemos em linhas gerais a trama de América, ou O desaparecido (escrito entre 1911 e 1914, publicado em 1927). O protagonista da narrativa é Karl Rossmann, jovem inocente e encantador de uma família alemã de baixa classe média, mandado aos Estados Unidos por seus pais após ter engravidado uma faxineira. Na cena inicial, ele chega ao porto de Nova Iorque avistando a "estátua da deusa da liberdade", enquanto é empurrado pela numerosa multidão que deixa o navio. Depois disso, passa por toda sorte de acasos, embaraços e peripécias em sua jornada pelo país, começando pelo episódio da perda de uma mala no porto, que o leva a ter um longo diálogo com o foguista da embarcação (este capítulo chegou a ser publicado isoladamente por Kafka). Entra em contato também com um tio, rico e excêntrico, que oferece uma acolhida ao

128 mesmo tempo feliz e inusitada ao sobrinho; junta-se a trambiqueiros, patifes, bufões e artistas ambulantes; flerta com simplórias camareiras, ascensoristas e camponesas; e, afinal, descobre no "Grande Teatro Natural de Oklahoma" uma promessa de repouso e bem aventurança, pois nele "todos são bem-vindos para participar na grande peça do mundo".

Mas, nesse ponto, pequenos detalhes sobre o funcionamento do teatro parecem ir contra essa expectativa. E as páginas em que ele é descrito oferecem mais motivos de estranhamento do que de conforto para o leitor. Ou, como escreveu Jorge Luis Borges, ao mencionar o livro em um breve ensaio: "Esse teatro infinito não é menos populoso que o mundo, e prefigura o Paraíso (traço muito pessoal: nem mesmo nessa figura do céu os homens conseguem ser felizes, e há ligeiras e diversas demoras)" (BORGES 1998a, p. 113). E isto deve bastar para se entender porque, no dia 8 de outubro de 1915, após ter lido algumas passagens do David Copperfield de Dickens, Kafka anotou em seu diário:

"O foguista" é uma simples imitação de Dickens, e o será ainda mais o romance projetado. História da mala, o protagonista que alegra e encanta, os trabalhos humildes, a amada na casa de campo, as casas esquálidas, etc., mas sobretudo o método. Agora me dou conta que minha intenção era escrever um romance de Dickens, enriquecido unicamente com as luzes mais penetrantes provenientes de meu tempo, e com as outras, mais tênues, provenientes de meu interior, onde estão escondidas (KAFKA 1995, p. 338). 
De tal modo que América está em uma posição bastante singular na história da literatura. É um epílogo e também um começo; na evolução que acompanhamos até aqui, é o último romance do século XIX, e o primeiro do século $X X$. Nele, o "método de Dickens" se traduz na acumulação de ações e personagens insólitos, que aparecem e desaparecem durante a busca por um novo lar do forasteiro libertado de suas origens, levando-o a encontrá-lo em um desfecho redentor. Por outro lado, embora seu modo ficcional predominante seja o cômico, na alegria do encerramento persiste a suspeita de que alguma coisa não anda bem. O Grande Teatro Natural de Oklahoma por pouco não é o paraíso - mas este pouco significa uma grande mudança. Ele é uma falha insidiosa e sutil, mas por isso mesmo mais notável e desconcertante, no tipo de arranjo alcançado nos finais de Dickens, que agora são atingidos pelas luzes, e pelas sombras, do tempo de Kafka.

Com isso, se o modo cômico atualiza e reforça as forças de identidade e associação que por fim conferem uma 'forma' bem delimitada à narrativa, o que temos agora é uma importante intrusão dos vetores de dissociação, desacerto e diferença justamente no instante em que esta forma deveria consolidar-se. Qualquer desfecho que articulasse plenamente os elementos do texto em uma ordem fechada, afinal, seria inverossímil diante do caráter mais conturbado e fragmentador do novo ambiente histórico que se anunciava. Nesse contexto, a imposição de rotinas convencionais à matéria literária ficava restrita aos romances populares que - estes sim - limitavam-se a 'imitar' os protocolos do legado oitocentista. Ao invés de circunscrever sua narrativa a um modelo desgastado, portanto, Kafka permitiu que o modo trágico lançasse uma suspeita sobre a aparente felicidade de sua conclusão.

Depois, em $O$ processo (concluído em 1915, publicado em 1925), este mesmo desdobramento seria exibido com maior impacto, recebendo aí sua versão mais completa e conhecida. Para isso, bastou inserir também no início da trama uma lacuna que teria consequências decisivas em todo o restante do percurso: ao ser acusado de um crime indeterminado, com base em uma lei cujo conteúdo permanece oculto, Joseph K. não sabe sequer por onde começar a trajetória de sua redenção. Deste modo, como em tantos romances de Dickens, tudo se passa nos labirintos da jurisprudência, em meio a trâmites disparatados e arbitrários, que às vezes se assemelham a fantasmagorias e assombrações; mas, se em Dickens estes acabam por se revelar como desvios pontuais de uma sociedade que afinal se reintegra em um todo coeso, após uma série de confusões e uma aparente desorientação geral, em Kafka as diferentes partes da máquina burocrática em momento nenhum se reúnem em um conjunto dotado de sentido: elas parecem continuar operando de maneira apenas automática, uma vez que seus fundamentos foram esquecidos.

Os personagens de Kafka, portanto, transitam entre os estranhos fragmentos de um mundo cuja organicidade um dia fora assegurada pela possibilidade de um senso comunitário, deliberadamente ingênuo e simplificado, de caráter oscilante e atualização necessária em cada narrativa. Quando esse senso deixa de flutuar em torno de suas mediações para assumir a natureza de uma lei formalista, regimental, a resultante é uma série de operações insólitas 
e intermináveis, destituídas da finalidade última que a experiência oitocentista configurava no encerramento de suas comédias. Com isso, fica assinalado um possível entendimento da passagem do século XIX ao XX no campo da literatura europeia: não por acaso, em uma trajetória expositiva que se iniciou com a análise de um relato sobre um migrante europeu chegando aos Estados Unidos da América - a novidade de maior impacto no ambiente histórico do ocidente no século $X X$.

Porém, a literatura estadunidense apresentou um conjunto de gêneses, variações e transformações próprias no campo da narrativa, com maior ênfase, desde o começo, para o modo trágico, como será verificado a seguir. Ou seja: enquanto, entre outros autores, Kafka assinalava a inesperada irrupção de elementos fragmentadores, dispersivos e angustiantes em meio à regularidade da experiência burguesa europeia, os vetores da dissociação trágica foram desde antes constitutivos de evoluções particulares da cultura política, econômica e literária nos Estados Unidos, em particular por conta de um dinamismo individualista de caráter mais radicalizado e violento. Portanto, se a traumática eclosão da Primeira Guerra Mundial pode ser considerada um marco no declínio da crença em uma possível harmonia entre as nações na modernidade, isso se deu também porque tal expectativa foi gerada na mesma forja que reformulou os hábitos negociadores e confiantes da comédia romântica, e depois os converteu em convenções mecanizadas e inverossímeis, elas próprias responsáveis pelo fracasso de suas motivações originais. Enquanto, do outro lado do Atlântico, já se convivia com o ambiente de polarizações radicais e intransigência ética que teria maior relação com o ambiente histórico do século XX.

\section{Visões do Apocalipse}

Em uma breve resenha sobre Bartleby, the Scrivener: a Story of Wall Street (1853), de Herman Melville, Jorge Luis Borges compara o famoso relato do escritor estadunidense às "fantasias de conduta ou do sentimento" que seriam depois elaboradas por Franz Kafka. No entanto, segundo o argentino, "as páginas iniciais de Bartleby não pressentem Kafka; antes, aludem ou repetem Dickens" (BORGES 1998 b, p. 125). Curiosamente, o mesmo ponto foi assinalado por um comentarista tão distinto de Borges quanto Gilles Deleuze, em um ensaio onde a narrativa de Melville é assim descrita: "Tudo começa como num romance inglês, em Londres e de Dickens. Mas a cada vez algo estranho se produz e turva a imagem, afeta-a com uma incerteza essencial, impede que a forma 'pegue'". Então temos também aqui uma espécie de passagem da Europa à América do Norte, análoga à que foi verificada no primeiro romance de Kafka. Ou, como afirma Deleuze, ainda sobre o relato de Melville, "tudo começa à inglesa, mas continua-se à americana, seguindo uma linha de fuga irresistível" (DELEUZE 1997, p. 89).

Esta será também, como foi indicado, a linha da análise comparativa a ser empreendida a seguir. A literatura surge então, mais uma vez, como um fenômeno em que as dinâmicas relacionais de uma cultura dominante são exibidas tanto em sua consistência própria quanto em suas contradições e dissenções internas. Porém, agora, em uma cultura que a princípio se caracteriza pela ênfase na 
dissociação e na desintegração das 'formas', pelo repúdio a qualquer common sense que sacrifique um impulso conquistador ou as prerrogativas da vontade em favor de uma moralidade flutuante e negociada. Assim, enquanto na Europa a exacerbação de conflitos irreconciliáveis no início do século XX marcou a derrocada de uma experiência política de direcionamento unificador, nos EUA a marcação de posições intransigentes e sectárias esteve vinculada ao próprio processo de formação nacional, feito de oscilações mais bruscas, violentas e descontroladas em diversos campos da atividade humana.

Neste tópico, a menção ao Bartleby chama a atenção, em primeiro lugar, para o caso das transformações no ambiente das cidades. A história do indivíduo anônimo, destituído de uma família ou de um passado, e com uma voz tão idiossincrática quanto a do escriturário de Melville, só poderia mesmo vir atrelada desde o título ao cenário nova-iorquino, onde foram sentidas pela primeira vez as maiores consequências da liberação das forças do alto capitalismo. A ideia de explosão urbana carrega inclusive uma dimensão catastrófica que faria as capitais europeias do final do século XIX parecer comunidades provincianas. $\mathrm{E}$, nos Estados Unidos em particular, o isolamento e o desamparo do indivíduo nas grandes cidades podem ser vinculados mais diretamente a um conjunto de valores culturais preponderantes, os mesmos que tornaram prescindíveis ou até indesejáveis os sistemas de proteção social do welfare State europeu.

No campo macroeconômico, a nova dinâmica pode ser também observada. Pois, se o capitalismo oitocentista já sofria com variações cíclicas entre períodos de crescimento e recessão, estas eram ainda modulações flutuantes, que se mantinham próximas a um curso mediano, de modo que fosse preservada a confiança em um gradual desenvolvimento de suas potencialidades. Contudo, com o aumento da participação norte-americana na economia mundial, ganha novas dimensões o fenômeno da depressão, isto é, uma brusca linha descendente, que se segue a uma época de euforia, e é marcada por demissões em massa, falências em série e uma angústia generalizada quanto ou futuro. Tudo isso implica um grau de exposição ao risco e à fragmentação do tecido social que a experiência europeia desconhecia. Daí os inúmeros casos de retumbantes insucessos descritos por Scott Sandage em Born Losers: a History of Failure in America (2005), um estudo que atesta a convivência dos estadunidenses com a iminência constante da catástrofe e do arruinamento pessoal.

Voltando à terminologia mobilizada na discussão aqui proposta, pode-se dizer que tudo isso converge para a percepção de um viés trágico nos produtos e práticas culturais estadunidenses. Ou, dito de outro modo, para uma maior preponderância das forças da exceção, do individualismo e da insociabilidade nas relações internas de cada fenômeno, resultando em um ambiente histórico bem mais instável e atravessado pela ideia de crise. No âmbito literário, cabe lembrar então um conjunto de ensaios de D. H. Lawrence, reunidos em 1923, sobre a "literatura clássica norte-americana", em que as obras de Nathaniel Hawthorne e Herman Melville, entre outras, são consideradas expressões de uma radicalidade trágica fundamental, a que as vanguardas europeias de então somente almejavam reativamente, por desgosto com a falência do 
mundo burguês oitocentista. Nas palavras de Lawrence, os europeus modernos estavam tentando ser radicais, enquanto os estadunidenses "simplesmente eram" (LAWRENCE 1951, p. 18).

Trata-se, portanto, de um eixo de representações desvinculado das formas desenvolvidas pela tradição moderna europeia, e que em muitos casos parece inclusive ignorá-las ou desconhecê-las, ao privilegiar um discurso que coloca em cena as forças caóticas de um universo recém-nascido. Daí a retomada do Velho Testamento como um dos conjuntos de narrativas de maior afinidade com as da literatura estadunidense, em sua confusa, violenta e paratática irrupção de mandamentos éticos radicais pela voz de profetas e déspotas alucinados. Então, também em um caso como no outro, proliferam condutas heterodoxas, maníacas e extravagantes, de uma brutalidade ou estranheza que as tornam imunes a quaisquer enquadramentos morais já conhecidos, e sem que haja um senso comum solidamente compartilhado a servir de balança em seu julgamento. Ao mesmo tempo, instala-se a sensação de urgência, de crise, de abertura e instabilidade do tempo histórico.

Em uma intermitente linha de semelhanças comparativas, seria possível recorrer ainda às tragédias de Shakespeare: igualmente estranhas em termos de sua estrutura formal, posto que destituídas de agentes internos capazes de agir com habilidade prática na solução de seus conflitos dramáticos, e mais propriamente acionadas pelas vontades, caprichos, delírios e impulsos heroicos de indivíduos isolados. Para exemplificar sua associação à literatura dos EUA, 132 basta lembrar como a vontade delirante de Ahab, o protagonista do Moby Dick (1951) de Melville, é também a de Macbeth, e como uma projeção inescapável em direção ao desastre, por força da intransigência pessoal, está tanto em Otelo quanto na figura do reverendo Dimmesdale, em The Scarlett Letter (1850), de Hawthorne. Passando enfim a um registro narrativo contemporâneo, cabe notar como a alternação de mesquinharias, atrocidades e loucuras em Rei Lear, bem como seu longo tour de force que culmina em uma catástrofe sangrenta, foi lembrada por alguns dos espectadores e comentaristas do seriado televisivo Breaking Bad (2008-2013).

De Walt Whitman a Walter White, portanto, a narrativa estadunidense seguiu produzindo artefatos com grandes doses de som e de fúria. Quanto ao período pós-1945, a falta de distanciamento temporal impede a concentração da análise em um par de autores representativos do período, mas nem por isso tais recorrências deixam de ser observadas em um conjunto ampliado. Ganham destaque, então, a truculência subjacente aos romances de William Faulkner e aos contos de Flannery $\mathrm{O}^{\prime}$ Connor, incorporando ainda narrativas de um momento anterior; os atos sangrentos e repulsivos que desencadeiam em narrativas de James Baldwin (particularmente em Go Tell it on the Mountain, de 1953), Harper Lee (To Kill a Mockinbird, 1960) e Truman Capote (In Cold Blood, 1966); as desastrosas e massacrantes reversões da fortuna que acometem personagens de Arthur Miller (Death of a Salesman, 1949), William Kennedy (em todo o ciclo de Albany), Philip Roth (com destaque, neste tópico, para American Pastoral, de 1997); e os cenários apocalípticos e pós-apocalípticos de autores como Don 
Delillo (White Noise, 1985), Tony Kushner (Angels in America: a Gay Fantasia on National Themes, 1993), e Cormac Macarthy (The Road, 2006), entre outros.

Nestes últimos, aliás, fica bem representada a observação feita por Frank Kermode, em um ensaio de The Sense of an Ending (1967), de que a imaginação do Apocalipse teria uma dimensão paradigmática para o ofício ficcional na segunda metade do século XX. As narrativas do "fim do mundo" e do "pós-fim-do-mundo" se tornariam inclusive um dos grandes fenômenos de interlocução entre a cultura literária dos EUA e sua indústria de entretenimento, com a proliferação de best sellers, longas-metragens e séries televisivas sucessivamente reproduzidos nessa chave, assim como aconteceu com a comédia romântica, no caso inglês. Ficam então as perguntas: em um contexto histórico marcado pela percepção de uma crise contínua a pela iminência da catástrofe, qual seria o lugar do modo cômico, que não o de uma simples sobrevivência, agora ainda mais inverossímil e desconectada do mundo, de velhos hábitos e convenções formais vazias, mobilizadas para o consumo de massas? E de que maneira as inclinações mais espontâneas para o acordo, a negociação e um relativo otimismo quanto ao futuro poderiam surgir aí? Como a questão dos contrapontos modais na narrativa pode contribuir para a compreensão do sentimento histórico pós-1945?

\section{Raymond Carver: o sonho de reconciliação}

Será possível apenas indicar um caminho de uma resposta neste espaço, antes com a abertura de uma discussão do que com um desfecho conclusivo. Essa indicação ficará a princípio restrita à própria narrativa estadunidense, voltando-se para os contos de Raymond Carver. Mas antes deve ser lembrada também a imensa repercussão que a obra do autor russo Anton Tchekhov teve não só em sua obra, mas também na de vários outros autores estadunidenses de características semelhantes.

O ponto a ser ressaltado, aqui, está no fato de Tchekhov ter afirmado em diversas ocasiões ser um autor de comédias. Decerto, pode haver certa ostentação de modéstia nesse tipo de declaração por parte do autor. Mas ela também reproduz algo da genuína simplicidade de espírito e de forma que atravessa seus contos e peças. Pois os personagens de Tchekhov são de fato destituídos das ambições desmedidas, da inteligência maldita ou dos impulsos passionais que caracterizam os protagonistas trágicos de Shakespeare. E, por mais que possam desconhecer também a alegria humilde e otimista das configurações cômicas oitocentistas, é para ela que normalmente se voltam suas aspirações, mesmo que as condições dadas pelo contexto de cada texto insistam em frustrá-las. Ou seja: tudo, em Tchekhov, se passa ao rés-do-chão, no plano de uma humanidade já decaída, sem que nenhuma nova queda de grandes proporções seja encenada nos relatos. Com isso, há até certa leveza na desgraça, com a observação da comédia humana como reunião de idiossincrasias e particularidades desconectadas, mas que não deixam de buscar pontos de contato e de encontro, por mais atrapalhadas, incertas e difíceis que essas tentativas possam ser. 
Curiosamente, a fala inicial de $A$ gaivota (1896) - quando uma personagem abre a peça declarando estar de luto, porque é infeliz - faz repercutir na memória as de All's Well that Ends Well (1605), The Merchant of Venice (1598) e Twelfth Night (1602), todas elas com referências a funerais e à tristeza de seus protagonistas. Porém, na peça de Tchekhov, as dificuldades encontradas para reverter esta situação são maiores e mais concretas, uma vez que estabelecidas por um ambiente mais hostil e desesperançado. Já em "A dama do cachorrinho" (1899), o conto mais famoso do autor russo, observa-se uma trama em que os acertos e desacertos de um casal acompanham em vários aspectos os passos de uma comédia romântica comum, mas com um desfecho marcado pela incerteza, que respeita a percepção daquelas dificuldades e o senso de verossimilhança dos leitores. De maneira que há em Tchekhov um realismo substancial que o impede de trabalhar com fórmulas e modelos narrativos rígidos, mesmo quando tudo parece apontar neste sentido. Nem por isso, no desfecho de O jardim das cerejeiras (1904), sua última peça, deixa de existir certo alívio e felicidade na solução encontrada para a narrativa.

Em resumo, pode-se dizer que a obra de Tchekhov assumiu uma importância crescente no século $X X$ porque ela reconhecia os impasses de uma nova conjuntura histórica cujos desdobramentos só reafirmariam seu diagnóstico. E sua influência na literatura dos Estados Unidos está atrelada a este fator, uma vez que a percepção de ambiente fragmentado e desnorteante seria aí sentido em grandes proporções, sobretudo por aqueles destituídos do ímpeto conquistador responsável pelos ressonantes sucessos e grandiloquentes fracassos dos novos tempos. Raymond Carver, um típico loser para os padrões da sociedade estadunidense, foi um desses indivíduos - porém sem que essa experiência tenha se convertido na representação de um desespero existencial de dimensões trágicas ou de uma combatividade marginal, também frequentes na literatura estadunidense. Sua obra, decerto, é atravessada pela tragédia social que determina suas situações narrativas, mas até por isso a inserção dos vetores de concórdia e conciliação em seus textos se torna relevante.

Em Carver, portanto, tudo se mantém em um plano de perrengues muito humanos, desapontamentos cotidianos, vilezas corriqueiras e aspirações bastante simples por instantes de paz que atenuem o sofrimento. Sem dúvida, muito pouca coisa é conquistada nesse sentido, mas no contraste com o horizonte de expectativas, este pouco ganha outras proporções. Assim, em um manejo objetivo da linguagem, a solidão, a pobreza, o alcoolismo e o desemprego são em seus contos as bases de pequenos êxitos literários em que não deixam de estar presentes certo enternecimento, gestos de cortesia e uma delicada articulação dos signos do texto. Algumas dessas modulações se perderam com o corte de longos trechos de seus contos por Gordon Lish, o editor responsável pelas primeiras coletâneas de Carver, entre elas a então intitulada What We Talk about When We Talk about Love (1981). Mas hoje, após o lançamento das versões completas das narrativas deste mesmo livro (Beginners, 2009), as variações e contrapontos modais de Carver podem ser mais bem avaliados. 
A própria divergência entre o nome escolhido por Carver para o livro e o titulo mais sofisticado da edição de Lish já indica uma diferença importante entre as duas perspectivas de leitura criadas por cada um. Com "Sobre o que Falamos quando Falamos de Amor", temos uma sobreposição de camadas que insinua significados ocultos para o discurso, de teor mais intelectualizado e analítico; com "Iniciantes", os personagens do relato homônimo são apenas anunciados como criaturas desprovidas de um referencial dado pela tradição ou pelo bom senso para orientar sua conduta, e que vão tateando (muitas vezes de modo desastroso ou precipitado) em busca de um território comum para suas concepções sobre o amor. Enquanto isso, nos demais contos do livro, bem como nos de Cathedral (1983), já publicados sem a interferência de Lish, as precipitações e equívocos generalizados muitas vezes encontram seu reverso em imagens delicadamente construídas e insertadas com precisão no decorrer das narrativas. É o caso das cenas de uma felicidade caseira e provisória em "Distance", "Where I'm Calling from" e "Menudo".

Já em relatos como "Fever" e "A Small, Good Thing", temos composições de maior fôlego que conseguem oferecer algum tipo de amparo para as situações traumáticas vividas por seus protagonistas. Esse conforto é sempre também breve e pontual, mas assinala uma promessa de restabelecimento que basta para definir a forma dos textos, em uma inesperada contraposição de modos ficcionais. Contos como estes, vale notar, estiveram atrelados a uma experiência de recuperação do alcoolismo pelo próprio Carver, cujo sucesso influiu também no que há de alegria e satisfação com a vida em seus últimos poemas. Desta maneira, assim como Stephen Greenblatt (2004) associou todo o conjunto de comédias de Shakespeare a um "sonho de reconciliação" gerado por uma falência familiar, em Carver há a expressão de um anseio análogo pela reversão de outros fracassos e misérias. Ao mesmo tempo, enquanto a voz dos excluídos de uma sociedade reconciliada repercute na resolução dos textos de Shakespeare, em Carver a ação se dá em todos os momentos em um ambiente de exclusões e irresolução constantes, e por isso a maior ênfase na leitura recai no que é conquistado em termos de inversão dessas circunstâncias.

\section{Considerações finais}

Com isso, é possível retomar uma conclusão anterior e completar o quadro comparativo que vem sendo elaborado. Verificou-se que, no panorama geral, a cultura britânica oitocentista foi uma cultura da comédia romântica, da conciliação reformista e de habilidosos arranjos retificadores do mundo. Porém, no detalhe, dava-se uma suspensão dessa segurança, imiscuindo-se nela uma angústia irremediável e fundamental. Já a visão de conjunto oferecida pela grande narrativa estadunidense, mais diretamente associada ao século $X X$, é trágica e apocalíptica, implicando a ideia de um mundo entregue a potências devastadoras. Mas no pormenor, no trabalho mais minucioso da narrativa breve e no esforço cotidiano pela sobrevivência nesse ambiente, podem ser notados traços revigorados de formas e valores atribuídos a uma índole cômica, ainda que essencialmente modificados por sua inserção nesse contexto. 
Pois, para qualquer artista vinculado ao sentimento histórico dessa época, tornou-se impossível conceber soluções abrangentes e providenciais para seus conflitos. A tragédia passa a ser um pressuposto, um dado da existência e um condicionamento geral que afeta até mesmo as narrativas mais simples e despretensiosas. Porém, uma vez presumida a crise, quando o estado de exceção torna-se regra, os movimentos internos do texto podem atuar de maneiras distintas em relação a ele. E com frequência se observam, nos movimentos internos do conto e do drama contemporâneos, determinados agentes que atenuam e conferem certa leveza a esse quadro, estabelecendo um contraste relevante com o quadro ampliado, a big picture de onde emergem, e criando também possibilidades, ainda que precárias e frágeis, de algum alívio, de algum conforto e inclusive de alguma alegria em meio à catástrofe.

E quando, da inadequação e da perplexidade generalizadas, surge um simples gesto capaz de reverter esses sentimentos em seus contrários, estamos diante de um acontecimento tão efêmero quanto fundamental para a experiência da contemporaneidade, e do sentimento histórico de nossa época. Algo semelhante acontece na dramaturgia cinematográfica em filmes como Lost in Translation (roteiro e direção de Sofia Coppola, 2003), onde são exibidos motes e dinâmicas da comédia nas situações vividas por seus personagens, porém em um ambiente de confusão e alheamento que impede qualquer conclusão formal definitiva, e aceita como desfecho apenas um breve sussurro, tão verossímil quanto inesperado. E nisto se evidencia a

136 transformação mais importante dos atributos associados ao gênero. Sem mais remeter a formas e gestos registrados pelo senso comum ou pela tradição, eles perdem o caráter convencional e conservador para assumir uma função totalmente criativa, uma vez que somente o improviso e o ineditismo são capazes de atualizar suas funções.

Enfim, uma vez desfeito um pensamento sobre a história capaz de conferir sentido e unidade aos seus movimentos (algo característico da experiência moderna europeia, e cuja derrocada a obra de Kafka já indicava), ficamos diante de um cenário de crescente ansiedade quanto a um futuro incerto. $\mathrm{E}$, se a monotonia das convenções burguesas e o fastio com suas normas de decoro desgastadas teve um papel importante na configuração do ambiente artístico no início do século XX, agora a sensação de instabilidade talvez demande outros direcionamentos. Mas a situação é de tal complexidade que quaisquer soluções já conhecidas são insuficientes e inadequadas para os novos problemas, assim como as fórmulas otimistas dos livros de autoajuda antes aumentam do que atenuam o efeito das patologias contemporâneas. Por isso, trata-se de recuperar algo de nossa disposição natural, espontânea e criativa para o encontro e o compartilhamento, na esperança de que ela seja capaz de continuar gerando formas em um mundo informe. Entretanto, como foi assinalado, este é ainda o esboço de uma linha de raciocínio, que poderá ser desenvolvida com maior amplitude em estudos futuros. 


\section{Referências bibliográficas}

BORGES, Jorge Luis. Franz Kafka. A metamorfose. Trad. Josely Vianna Baptista. In: Obras completas de Jorge Luis Borges. Vários tradutores.

São Paulo: Globo, 1998a [1938], vol. 4, p. 112-114. . Herman Melville. Bartleby. Trad. Josely Vianna Baptista. In:

Obras completas de Jorge Luis Borges. Vários tradutores. São Paulo: Globo, 1998b [1944], vol. 4, p. 125-127.

DELEUZE, G. Bartleby, ou a fórmula. In: Crítica e clínica. Trad. Peter Pál Pelbart. São Paulo: Editora 34, 1997 [1993], p. 80-103.

FRYE, Northrop. A Natural Perspective: the development of Shakespearean comedy and romance. New York: Columbia University Press, 1965.

Anatomy of Criticism: Four essays. Princeton: Princeton University Press, 1957.

GREENBLATT, Stephen. Como Shakespeare se tornou Shakespeare. Trad. Donaldson M. Garschagen e Renata Guerra. São Paulo: Cia. das Letras, 2011 [2004].

GUMBRECHT, Hans Ulrich. After 1945: latency as origin of the present. Stanford: Stanford University Press, 2013.

KAFKA, F. Diarios (1910-1923). Edición a cargo de Max Brod. Trad. Feliu Formosa. Barcelona: Fabula Tusquets, 1995.

KANT, Immanuel. Ideia de uma história universal de um ponto de vista cosmopolita. Organização Ricardo R. Terra. Trad. Rodrigo Naves e Ricardo R. Terra. São Paulo: Martins Fontes, 2003 [1784].

KERMODE, Frank. The Sense of an Ending: studies in the theory of fiction. New York: Oxford University Press, 1967.

KRACAUER, Siegfried. Sobre livros de sucesso e seu público. In: 0 ornamento da massa: Ensaios. Trad. Carlos Eduardo Jordão Machado e Marlena Holzhausen. São Paulo: Cosacnaify, 2009, p. 105-116.

LAWRENCE, D. H. Studies in Classic American Literature. New York: Doubleday \& Company, 1951 [1923].

MAGARSHACK, David. Chekhov, a Life. Westport: Greenwood Press, 1952.

SANDAGE, Scott A. Born Losers: a history of failure in America. Cambridge: Harvard University Press, 2005.

SKLENICKA, Carol. Raymond Carver: A writer's life. New York: Scribner, 2009. TRILLING, Lionel. Sincerity and Authenticity. Cambridge: Harvard University Press, 1972. 